\title{
Post-Tiananmen Chinese Communist Party Religious Policy
}

\author{
ANTHONY P. B. LAMBERT
}

\section{Introduction}

The Beijing massacre of June 1989 has had a profound effect on the religious policy of the Chinese Communist Party (CCP), as it has had in every field of Chinese society. Prior to the sudden swing back to a hard-line political position, there had been many signs of a thaw in the offing in Chinese religious policy. ${ }^{1}$ In 1988 daring voices in both the Protestant and Catholic Churches in China had spoken out in strong terms condemning the government's 'patriotic' religious associations as puppets of the party and as having lost all credibility among ordinary religious believers. They had called for the radical liberalisation, even abolition, of both the Protestant Three Self Patriotic Movement (TSPM) and the Catholic Patriotic Association (CPA). ${ }^{2}$ During the high tide of the democracy movement in May-June 1989 many theological students from both the Protestant and Catholic 'patriotic' seminaries had taken part in demonstrations supporting the student movement. Bishop Ding, head of the TSPM and of Nanjing Seminary, had himself come out in support of the students' demands. Ironically, the very theological students who had to undergo regular political indoctrination to ensure their loyalty to the communist system were calling for greater religious freedom and for democratisation of China. ${ }^{3}$

These hopes were shattered by the events of 3-4 June 1989 when the party old guard called in the People's Liberation Army to crush all dissent and ensure the survival of totalitarian one-party rule. The very survival of the regime was at stake and Deng Xiaoping and his elderly party colleagues have since made it plain that 'bourgeois liberalisation' and 'peaceful evolution' (to a pluralistic society on a western model) are not options they will countenance. Communism may have collapsed elsewhere, but in China, the CCP leadership are determined to shore up the system by every means possible. The present push by Deng Xiaoping since early 1992 to rejuvenate the economic reform plan should be seen in precisely these terms. Deng is willing to experiment with fast economic reforms, not in order to introduce western democracy, but to preserve CCP dominance.

\section{The Eastern European and Soviet Connection}

Religious policy in China cannot be understood outside the context of overall CCP policy. Since the founding of the People's Republic of China religious affairs have not generally occupied the attention of China's top leaders. Religious affairs have been dealt with in the framework of United Front work policy, with the Religous Affairs Bureau and local CCP organs controlling the various 'patriotic' religious associations. In 1950 Premier Zhou Enlai met leading Protestant church figures in Beijing, but since then such top-level concern has been conspicuous by its absence. However, 
since 1989 everything has changed. The collapse of communism in the citadel of Leninism itself has sent profound shock-waves throughout the Chinese intelligentsia and party establishment. The short-lived Soviet coup in August 1991 caused rejoicing in hard-line CCP circles, to be followed by consternation, even panic, when it collapsed.

The 'leftists' in the CCP leadership regarded with alarm the role played by Christianity in hastening the downfall of Marxist regimes in Eastern Europe. In particular, the politico-religious activities of the Vatican and of the church-backed Solidarity movement in Poland aroused fears of a similar mass movement taking hold among China's working class, and suspicions that both the Catholic and Protestant churches in China could become bases for political subversion. Bishop Ding has argued persuasively that the situation of the church in China is very different from that of the church in Eastern Europe. ${ }^{4}$ Despite massive growth (particularly of the Protestant church), Chinese Christians remain largely apolitical. Independent housechurches and 'underground' Catholics loyal to the Vatican (as opposed to the statesponsored CPA) have been under CCP suspicion at the best of times and they realise that political participation in the democracy movement would be suicidal. However, it appears that party hardliners are not convinced, and the general trend since 1989 has been towards a distinct tightening of CCP religious policy in both theory and practice.

Another, and connected, reason for the sudden attention being given to religious affairs is the radical geopolitical change taking place in the former Soviet Union and Mongolia. China's 'national minority' peoples are becoming increasingly restive as they see the rapid democratisation of Mongolia and the five new independent states in Muslim Central Asia just across China's western and northern frontiers. According to reliable reports, Uygur Muslims in Xinjiang and Mongols in Inner Mongolia have demonstrated openly in several cities following the failure of the August 1991 Soviet coup, calling for independence from Chinese rule. In April 1990 Islamic separatists near Kashgar briefly rose in revolt to establish an independent 'Republic of East Turkestan'. The revolt was crushed by the Chinese army. On 5 February 1992 Muslim terrorists blew up a bus in Urumqi, the capital of Xingjiang, killing at least three people. ${ }^{5}$ In Tibet, too there have been demonstrations followed by repression, as has been well documented by Amnesty International. ${ }^{6}$ In each of these areas religion, whether in the form of Islam or Lamaist Buddhism, remains a potent force, inextricably interlinked with burgeoning nationalism. Religion can no longer be delegated to party subordinates to be dealt with as a minor irritant. Rather, it is now occupying the centre of the stage as a major focus of CCP concern. The People's Republic intends to maintain its political hold on the huge, under-populated regions, constituting more than 50 per cent of China's total land-mass, which are home to the Uygurs, Tibetans and Mongols.

\section{Changes in CCP Religious Policy}

CCP religious policy for the decade or so of Deng Xiaoping's 'open door' policy before the Tiananmen crackdown was enshrined in Document 19 of the CCP Central Committee of March 1982. This long, carefully crafted policy statement allowed religion to exist within state-controlled parameters. Perhaps deliberately ambiguous in some areas, such as the vexed issue of the Protestant 'house-churches' already springing up all over the country, in general it eschewed violent suppression of religion (as had been the norm during the Cultural Revolution period 1966-76) and reestablished a system of state control through the network of United Front, Religious 
Affairs Bureaus and 'patriotic' religious associations. ${ }^{7}$

Since the Beijing massacre the CCP has reiterated that there will be no change in the policy of 'freedom of religious belief'. However, there have been definite signs that whatever lip-service may be paid to this principle, party religious policy in theory and practice has veered (along with much else in Chinese society) towards the 'left'. Perhaps the first documentary evidence of this came from Shanghai in July 1990 in the form of an article by the head of Shanghai Religious Affairs Bureau, Wang Honkui. ${ }^{8}$ Written for party officials, the article stressed that their primary task was now to combat 'subversion' from overseas and to intensify the political indoctrination of religious workers in the TSPM and CPA. Wang singled out the activities of independent Protestant evangelists and 'underground' Catholics (loyal to the Vatican) as particular targets for attack. As Shanghai has a large Catholic and Protestant population, and is China's largest city, the article was probably an indication that hardliners in top government circles were prepared to launch an offensive against all religious dissidents. In language frighteningly reminiscent of the Cultural Revolution, Wang called for 'unrelenting effort in the struggle against those forces masquerading under the cloak of religion'.

The following month the Protestant Three Self Patriotic Movement (TSPM) held a meeting in Shanghai which was addressed by Bishop Shen Yifan, seen by many as the likely successor to Bishop Ding. Unlike Bishop Ding, who as we have seen had taken a moderate line in resistance to resurgent 'leftism', Shen thoroughly toed the party line. His work report was punctuated by continual references to the need to combat 'overseas subversion'. In a vitriolic diatribe Shen virtually declared war against every form of Christian minstry (radio, literature, training, teaching etc.) being undertaken by overseas Christians to support the church in China if such work did not have the approval of the TSPM. Shen also had harsh words for Chinese 'house-church' Christians who for reasons of conscience refuse to accept political control through the TSPM: 'They steal money, rape women, destroy life and health, spread rumours and destroy social order. Some even foment believers to oppose leadership of the party and seek to destroy the Three Self Movement... Selfappointed evangelists worm themselves everywhere and form reactionary organisations.' Having myself met many house-church leaders within China I can only state that such a view is a travesty of reality, while admitting that there are a few people on the fringes of the house-churches who have indulged in dubious practices.

At the same conference, Bishop Ding, in contrast, spoke out against 'leftist' excesses against the church and admitted that in many areas large numbers of Christians were gathering for unregistered meetings, outside TSPM auspices. He attacked the growing repression in many areas as 'leftist' cadres, sensing the political wind now blowing from Beijing, began to clamp down again on the church:

In some areas the authorities have closed down unregistered meetingpoints, that is, home-meetings. I think that our TSPM/China Christian Council organisations at every level should explain [to the government] that this lack of making distinctions is harmful to stability and to the nation... These meeting-points have many good Christians in them. We should protect them. We cannot take part in arbitrarily closing them down. ${ }^{10}$

Despite Ding's protestations, there is growing evidence that at grass roots level the church is again suffering quite severe repression in many areas.

In October 1990 a national meeting of the United Front Work Department and the Religious Affairs Bureau was held. While paying lip-service to the spirit of Document 
19 the conference seems to have concerned itself chiefly with the danger that religious believers, especially Christians, would indulge in 'peaceful evolution' to subvert the CCP through 'bourgeois liberalism'.11 This meeting was followed in December by a high-level conference convened by the State Council in Beijing, which summoned 200 senior officials to discuss religious policy. Premier Li Peng himself addressed the gathering in somewhat lacklustre tones. Among subjects reportedly discussed were the resurgence of Daoist secret societies (traditionally hotbeds for anti-government activities), the strained relations between Han Chinese and Muslims, and the vexed question of Sino-Vatican relations. ${ }^{12}$ In January 1991, CCP General Secretary Jiang Zemin officially stated the new party line in a meeting with the 'patriotic' leaders of the five officially recognised religions in China (Buddhism, Islam, Daoism, Protestantism and (non-Vatican) Catholicism). Jiang called for tighter control to prevent 'hostile forces across the border from using religion to perpetrate infiltration'. ${ }^{13}$

These high-level meetings were clearly convened in order to put the finishing touches to the CCP's new post-Tiananmen religious policy. On 5 February 1991 that policy was finally enunciated in the internally circulated Document $6 .^{14}$ In this authoritative statement by the State Council the main emphasis is on strengthening control of religious affairs and combating 'religious subversion' from overseas. Again, lip-service is paid to Document 19 of 1982 , which till in theory remains the CCP's cardinal point of reference as far as religious affairs are concerned. However, it now is to be interpreted, and in some instances at least to be replaced, by Document 6 . The new policy document expresses alarm at the proliferation everywhere of 'illegal' religious activities. In particular, unofficial theological seminaries, nunneries and scripture schools are mentioned as having sprung up to wrest the minds of China's youth from party control. (Much other documentary evidence could be cited to show that the CCP is seriously alarmed at the decline in party membership, while church attendance and membership soars.) All such activities, as well as the ubiquitous independent house-church evangelists, are to be suppressed. The document is aimed at tightening control within China against 'subversive' religious activities, and also at preventing overseas religous organisations from undertaking evangelism in any form. The document notes that in many areas officials have been slow to allow the restoration of churches and temples even to tolerated 'patriotic' religious bodies. In comparison with Document 19 the overall tone is distinctly 'leftist', and it offers clear proof that all effective liberalisation of religious policy, mooted in 1987-9, is now definitely still-born, and that the government is very much on the defensive. Frightened by religious revival and religious nationalism, it has reverted to mouthing the old slogans and, while tolerating religious worship, is seeking to repress religious fervour which spills beyond the narrow official bounds - a contradictory policy probably impossible to implement.

\section{Implementation of CCP Religious Policy at the Local Level}

China is a vast country. Central policies are sometimes interpreted and implemented in very different ways at the grass-roots level. This is particularly true of religious policy. Ethnic and religious differences combined with the attitudes of local cadres (friendly, indifferent or hostile) and other factors make analysis of the implementation of religious policy no easy task. Travelling through China to visit churches and Christian believers I have observed, for example, that CCP religious policy towards the church in Sichuan appears very tight and 'leftist'; however, in neighbouring Yunnan, although conditions for Christians have deteriorated since 1989, the 
situation is much more open than in Sichuan. A number of internal documents dealing with religious policy at the local level have been passed out to Hong Kong in $1990-2$ and these provide insights into how the central policy outlined above is being implemented at the provincial level and below.

Firstly, we may turn to an interesting document reporting on Islam in the Kashgar and Hetian areas of Xinjiang which was published internally in Xinjiang in $1991 .{ }^{15}$ It distills the 'comprehensive findings on religious problems' made by a fact-finding social studies team following the short-lived Islamic rebellion near Kashgar in April 1990. The report reveals how seriously alarmed the Chinese government is by the resurgence of Islam and separatist nationalism in Xinjiang. The researchers state that since 1987 a series of counter-revolutionary organisations has been uncovered in the area 'propagating jihad (holy war), advocating independence, whipping up national animosities, opposing the CCP, and overthrowing the socialist system'. They also reveal the extent of the Islamic revival in Xinjiang: 'Especially since 1984 there has been a frenzy of mosque-building.' 'Privately run scripture [quranic] schools not only refuse to close despite repeated bans, but run rampant. They have become hotbeds for the breeding of reactionary forces.' 'In all places more than half of the party members participate in religious activities and in certain rural areas the figure is 100 per cent.' 'Illegal religious activities are proliferating day by day. Some religious leaders do not allow people to go to the movies or watch TV and videos, nor are card-playing, toiletpaper, fashionable clothes or shoes allowed.' The researchers lament the fact that whereas the local ahungs (Islamic elders) are listened to with great respect, and many young men wish to become ahungs themselves, the authority of grassroots CCP cadres has been declining. Local people go five times a day to the mosque but rarely hear the voice of the party. Some CCP officials simply turn a blind eye to this recrudescence of Islamic fervour. In fact the power of Islam is so strong that simply to be born a Uygur or a Kazak is believed by the people to be the equivalent of being born a Muslim. The researchers call for a tighter system of party control of Islam. However, the general tone of the report is pessimistic and gives the impression that the CCP has lost control of the hearts and minds of the Muslim peoples of Xinjiang. It warns that because of Islamic indoctrination, 'once they are exploited by the separatists and pledged to jihad bolstered by their religion, thousands and tens of thousands of them will be coerced into walking the path of crime.'

More recent events in Xinjiang show that the local 'minority' peoples are indeed becoming increasingly restive under Chinese domination. The area has a history of turbulent Muslim rebellions against Chinese rule. With 60 million Muslims across their border in the newly independent republics of Central Asia, the Chinese seem faced with an intractable problem.

Secondly, let us look at three documents emanating from the rich coastal provinces of Fujian and Zhangzhou where the Protestant church has been expanding rapidly in recent years. It is now officially recognised that Zhejiang has over one million Protestant believers, and the true figure could be much higher. In rural Daishan County, Zhejiang, the local People's Government issued a circular in July 1991 to 'strengthen control of Christian activities'. ${ }^{16}$ The circular states that local authorities will implement the spirit of both Document 19 of 1982 and Document 6 of 1991, and calls on them to protect 'normal' religious beliefs and activities, to restrict and crack down on all types of illegal activities, to offer resolute resistance to the infiltration of unfriendly outside religious forces, and to strengthen control of Christian activities in the entire county. Already from the preamble it is evident that the thrust of the document is to restrict Christian activities. In fact, the regulations laid down are very 
'leftist' in tone. It is stated bluntly that all meeting places which have not registered with the authorities must close down, 'otherwise the appropriate departments will use coercive measures to force compliance. These include the confiscation of religious materials, equipment and properties used to conduct illegal religious activities.' A more open invitation to local 'leftist' officials to crack down on unregistered Christian activities could hardly be imagined. These authorities particularly target 'illegal preachers', and call for the Public Security Bureau to 'deal severely with them'. 'Those Christians who receive and give shelter to these preachers or know of their whereabouts without reporting them will also be severely dealt with.'

A document detailing draft TSPM regulations for controlling the church in northern Zhejiang was received in Hong Kong in June 1992. ${ }^{17}$ These regulations also call for strict control of the local church. 'The process of selecting committee members to manage the churches must be under the leadership of the relevant government departments at township and rural district level.' No church or individual is allowed to organise meetings without official permission or to preach outside the local limits laid down by the authorities. Everything has to be done in strict compliance with TSPM regulations. It is not surprising that many Christians in the house-churches and even within the TSPM-controlled churches are increasingly disturbed by the degree of political interference by the authorities in spiritual matters, as clearly instanced in such government documents.

In July 1991 a document was issued internally by the Public Security Bureau (PSB) in Zhangzhou, a city in Fujian Province, which gives further evidence of the concern of some local authorities to tighten control of the church and resist 'infiltration'. ${ }^{18}$ The eleven-page confidential circular attacks efforts made by Christian organisations overseas to 'evangelise China, Christianise Chinese culture and internationalise the Chinese church'. The PSB makes detailed mention of efforts by Christian pastors in Taiwan, Seventh Day Adventists, Hong Kong Methodists and other church groups to 'infiltrate' Zhangzhou by setting up secret Christian training camps for young people, establishing independent churches, distributing religious literature and so on in order to 'open up the door of China to the Gospel'. 'Some overseas Chinese tour groups openly propagate religion in public places, distributing religious propaganda.' 'Pastor Wu from Taiwan last year made 119 converts, including two CCP members and one Communist Youth League member.' The PSB calls for tighter surveillance and also for more political indoctrination of all registered church workers in Zangzhou to resist 'religious subversion'. The entire document is peppered with references to 'subversion' and 'infiltration' and gives a fascinating, if disturbing, glimpse into the Chinese communist bureaucratic 'leftist' mind as it wrestles with the problem of how to control unofficial religious activities.

\section{Conclusions}

The above documents are probably representative of thousands more which have not been leaked to the outside world. They give evidence of the alarming swing back to the 'left' of official CCP policy towards religion in the past three years. Despite lip-service to the concept of 'freedom of religious belief' (itself a peculiarly Marxist concept which in fact severely limits believers' rights both to practice and to disseminate their faith) the policy of the CCP both at the central and local levels has demonstrably retrogressed. Religion, whether Islam in Xinjiang, or Protestant Christianity rapidly multiplying in the Chinese heartland, is seen as a threat to political and ideological stability. It is a phenomenon to be controlled and, if possible, cut back. However, the 
authorities are in an impasse. Outright persecution of the type practised during the Cultural Revolution failed to stamp out religion. 'Leftist' religious policy has been shown to be bankrupt and self-defeating. All over China Protestants and Catholics revere the memory of the martyrs of the faith of the 1950s and 1960s. The Deng era of the past decade and more has seen a remarkable revival of religion throughout China. Moves towards genuine religious freedom which were mooted in the late $1980 \mathrm{~s}$ are no longer ideologically acceptable. The best the regime can attempt is to issue restrictions and snipe at religion. In some areas, repression of a vicious nature is still being practised, even encouraged. However, the authorities are on the defensive and in some areas at least no longer really in control of the situation. Strong-arm tactics may appear to work in the short term. But religion will only develop and expand 'underground', as, ironically, Document 19 admitted in a robust attack on 'leftist' religious policies.

The return of the government to bankrupt 'leftist' policies to deal with religious revival is symptomatic of a wider crisis in Chinese politics and society. People no longer believe in the party and its solutions. Religion is rapidly filling the ideological and spiritual vacuum caused by the collapse of Maoism. It is therefore virtually certain that the present post-Tiananmen repressive religious policy is only a transitional phase. China appears to be set on an inevitable path towards greater economic, and eventually political, freedom. The future of the CCP itself looks increasingly problematic. There is hope of eventual liberalisation of the situation for religious believers in China in the longer term.

\section{Notes and References}

1 I have summarised the evidence in Chapter 12 ('The cry for reform') in my book The Resurrection of the Chinese Church (Hodder and Stoughton, London, 1991).

2 See, for example, the calls by Zhang Shengcai (a house-church spokesman) and a former TSPM pastor in 1988 and early 1989 (The Resurrection of the Chinese Church, pp. 202-6).

3 I personally witnessed both Protestant and Catholic theological students demonstrating in Tiananmen Square, Beijing, on 18-19 May on the eve of martial law.

${ }_{4}^{4}$ Mimeographed Chinese text of Bishop Ding's speech at the National People's Congress, 6 September 1990.

5 South China Morning Post (Hong Kong), 22 February 1992.

6 South China Morning Post, 17, 22, 25 February; 5, 6, 12, 16 March 1992.

7 Original Chinese text of Document 19 (Tianjin People's Publishing House, August 1982) for internal circulation. The public version published in Red Flag, June 1982, was a sanitised version with key paragraphs excised showing clearly how the CCP controls the 'patriotic' religious bodies.

8 Handwritten copy in Chinese of article published by Wang Hongkui in the internal magazine for cadres, Shanghai United Front, July 1990.

- Tianfeng, November 1990.

10 ibid., pp. 21-2.

1 China News and Church Report, 24 November 1990.

12 China News and Church Report, 14 December 1990.

13 People's Daily, 1 February 1991.

14 Full Chinese text published in Bridge, October 1991.

15 Full Chinese text published in Bridge, December 1991.

16 Public Notice Concerning Strengthening the Control of Christian Activities in the Whole County (People's Government of Daishan County, Zhejiang Province, 5 July 1991).

17 Draft Regulations for the Management of Christianity in Pinghu City (Chinese typewritten script, undated but probably early 1992).

18 Infiltration Undertaken by Overseas Hostile Religious Forces against Zhangzhou City and Measures to Deal with Them (Zhangzhou City Public Security Bureau, 10 July 1991). 